\title{
PENGEMBANGAN AGROWISATA ANGGUR BERBASIS MASYARAKAT DI DESA BANYUPOH, KECAMATAN GEROKGAK, KABUPATEN BULELENG-BALI
}

\author{
I Gede Putra Nugraha \\ Jurusan Perhotelan (DIII), Universitas Pendidikan Ganesha \\ Singaraja, Indonesia \\ e-mail: dedenugraha@ymail.com
}

\begin{abstract}
Abstrak
Studi ini bertujuan 1) untuk mengetahui potensi agrowisata di Desa Banyupoh, 2) untuk mengetahui kekuatan, kelemahan, peluang dan ancaman dalam pengembangan Agrowisata di Desa Banyupoh.Data yang diperoleh bersumber dari hasil wawancara, observasi dan dokumentasi.Penelitian ini menggunakan deskriftif kualitatif. Subjek dari penelitian ini adalah petani atau masyarakat di Desa Banyupoh yang dapat memberikan data terkait, sedangkan objek dari penelitian ini adalah dengan menggunakan Analisis SWOT untuk mengetahui kekuatan, kelemahan, peluang dan ancaman. Hasil penelitian ini menyatakan bahwa 1) Desa Banyupoh memiliki potensi untuk perkembangan agrowisata, seperti perkebunan anggur. 2) Kekuatan Desa Banyupoh adalah perkebunan anggur yang dapat dijadikan sebagai daerah tujuan wisata petik anggur dengan menggunakan konsep "Petik Buah Langgsung dari pohonnya". Kelemahan Desa Banyupoh berdasarkan faktor dari dalam berupa tidak tersedianya sarana akomodasi, pemanfaatan atraksi alam yang kurang, aksesibilitas yang masih minim serta belum ada pemandu wisata atau lembaga terkait.Peluang yang dimiliki Desa Banyupoh dalam pemanfaatan potensi agrowisata adalah tren atau keinginan wisatawan untuk beralih kesuasana alam dan budaya menjadikan peluang yang baik dengan dikembangakannya wisata agro di Desa Banyupoh dengan memanfaatkan lahan perkebunan anggur. Ancaman yang dimiliki Desa Banyupoh adalah banyak munculnya desa wisata yang berbasis community based tourism, sehingga sehingga persaingan relatif ketat khususnya dengan wisata agro yang dipegang oleh Sababay Winery Bali.
\end{abstract}

Kata kunci: agrowisata, pariwisata berbasis masyarakat. SWOT

\begin{abstract}
The aim of the study are 1) to know the potential of agrotourism in Banyupoh village, 2) to know the Strength, Weaknesses, Opportunities and Treats in developingagro tourism in Banyupoh village. The data that found of a source from result the interview, observation and documentation. This research used descriptive qualitative. The subjek of this research is farmer or society in Banyupoh Village that can give the related data. Where leasobjectof this research is with use SWOT Analysis to know the Strength, Weaknesses. Opportunities and Treats. The result of this research explaint that are 1) Banyupoh Village has Potential to developingAgro tourism, such as grapes plantation. 2) TheStrength of Banyupoh village is grapes plantation that can will as the aim territory of pick grape with use concept"pick grape directly from the trees". The Weakness of Banyupoh Village be based on the factor from inside like not available accommodation medium, utilization of nature attraction that decrease the accessibility that still limited and the absence of tour guide or related institution. Opportunities of the Banyupoh Village in exploiting the potential of agro tourism is a trend or the development of agro tourism to switch to natural atmosphere and culture to make q good opportunity with the developing of agro tourism in the Banyupoh Village with land use wineries. Threats owned Banyupoh Village is much the emergence of tourism village based of community, so that relatively tight competition especially with agro tourism held by Sababay Winery Bali.
\end{abstract}

Keyword: Agrotourism, community based tourism, SWOT 


\section{Pendahuluan}

Bali merupakan salah satu destinasi wisata yang mempunyai ragam kebudayaan dan sumber daya alam yang berlimpah.Kekayaan alam merupakan modal utama dalam meningkatkan taraf hidup manusia melaui pemanfaatan sumber daya alam yang dimiliki.Bali mempunyai ciri khas dan daya tarik tersendiri yang dimana wisatawan lokal maupun wisatawan mancanegara tertarik untuk berkunjung ke Bali. Kabupaten Buleleng merupakan salah satu daya tarik wisata yang memiliki daya tarik tersendiri terutama sumber daya alam yang berlimpah.

Seiring dengan berjalannya waktu perkembangan pariwisata yang ada di Kabupaten Buleleng semakin pesat dengan adanya kesadaran masyarakat untuk memanfaatkan sumber daya alam yang dimiliki.Terlihat dengan adanya perkembangan pembangunan fasilitas seperti penyediaan akomodasi, restaurant dan faktor penunjang lainnya. Dengan dibangunnya fasilitas tersebut maka para wisatawan yang akan berkunjung ke daerah tujuan akan merasa betah dan nyaman untuk melakukan perjalanan wisata.

Kabupaten Buleleng mempunyai banyak daya tarik wisata.Seperti Pantai Lovina, Air Terjun Gigit, Taman Nasilonal Bali Barat, dan masih banyak yang lainnya. Selain memiliki daya tarik wisata, Kabupaten Buleleng juga memiliki lahan pertanian yang cukup luas dan banyak jenis tanaman yang ditanami misalnya seperti padi, jangung, kelapa, durian, cengkeh, dan tanaman yang paling banyak ditanam adalah tanaman anggur yang bertempat di Desa Bayupoh Kecamantan Gerokgak $\pm 56 \mathrm{Km}$ dari pusat kota Singaraja.

Perkebunan anggur merupakan salah satu sumber mata pencaharian bagi masyarakat di Desa Banyupoh. Selain posisi desa yang sangat strategis, sumber air yang ada di Desa Banyupoh juga sangat membantu dalam pengoprasian pengembangan tanaman anggur serta cuaca yang sangat mendukung. Selain memiliki kelebihan tersendiri, kesadaran akan pemanfaatan lahan perkebunan anggur nampaknya kurang. Masyarakat Desa Banyupoh kurang menyadari akan pentingnya pemaanfaatan lahan perkebunan bagi perkembangan dunia pariwisata, hal ini didasarkan pada observasi awal yang dilakukan.

Kurangnya kesadaran masyarakat akan pentingnya pemanfaatan lahan sebagai daya tarik wisata di Desa Banyupoh merupakan pokok permasalahan yang harus diteliti. Mengingat akan pentingnya agrowisata sebagai bagian dari objek wisata yang memanfaatkan usaha pertanian sebagai objek wisata. Tujuannya adalah untuk memperluas pengetahuan, pengalaman rekreasi, dan hubungan usaha dibidang pertanian.Melalui pengembangan agrowisata yang menonjolkan budaya lokal dalam memanfaatkan lahan, masyarakat bisa meningkatkan pendapatan petani sambil melestarikan sumber daya lahan, serta memelihara budaya maupun teknologi lokal yang umumnya telah sesuai dengan kondisi lingkungan alaminya.

Dari uraian permasalahan dilapangan maka perlu untuk melakukan penelitian dengan tema "Pengembangan Agrowisata Anggur BerbasisMasyarakat DiDesa Banyupoh, Kecamatan Gerokgak, Kabupaten Buleleng-Bali". Penelitian ini menggunakan konsep dasar syarat pengembangan pariwisata, yaitu $4 \mathrm{~A}$ (attraction, accesibility, ancillary, dan aminities)

Berdasarkan uraian latar belakang yang dipaparkan diatas dapat dirumuskan beberapa permasalahan sebagai berikut: (1) Faktor - faktor apa sajakah yang mampu mendukung pengembangan agrowisata di Desa Banyupoh?

(2) Bagaimanakah pengembangan agrowisatayang ada di Desa Banyupoh?

\section{Tipe Artikel}

Artikel ini merupakan hasil penelitian.Dimana penelitian ini dilaksanakan di desa Banyupoh Kecamatan Gerokgak Buleleng.

\section{METODE}




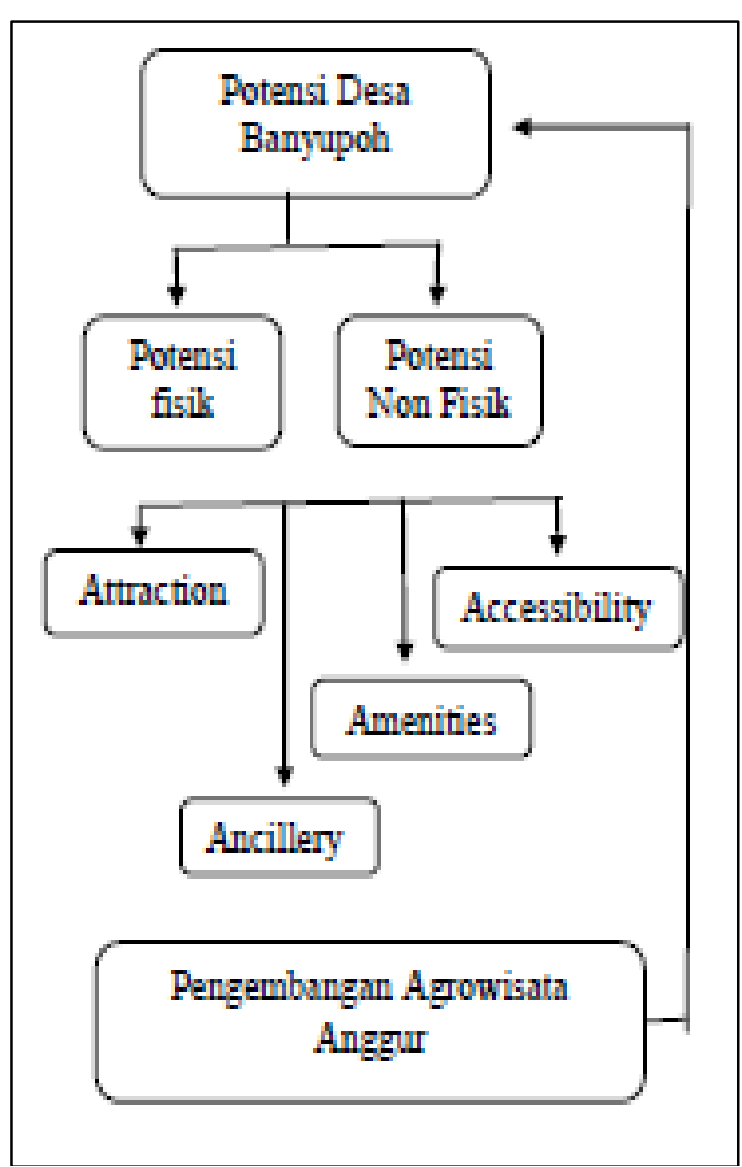

Bagan 3.1 Rancangan Penelitian

Dilihat dari bagan 3.1, Penelitian ini dimulai dari penelitian awal yang berlokasi di Desa Banyupoh Kecamatan Gerokgak Kabupaten Buleleng-Bali \pm 55 $\mathrm{km}$ dari pusat kota Singaraja. Desa Banyupoh memiliki potensi fisik berupa kondisi tanah, air, iklim dan sumber daya manusia (SDM) yang berkualitas, serta potensi non fisik berupa masyarakat desa, lembaga desa, aparatur desa, adat istiadat dan budaya. Dalam penelitian ini akan diteliti lebih lanjut dengan menggunakan kosnsep 4A (attraction, acceessibillity, amenities and ancillary).

Berdasarkan potensi yang dimiliki maka Desa Banyupoh layak untuk dijadikan sebagai daerah tujuan agrowisata.selanjutnya akan dilakukan Analisis SWOT (Strength, Weaknesses, Opportunities, and Threats) untuk mengetahui kekuatan, kelemahan, peluang dan ancaman. Dari proses analisis tersebut maka selanjutnya akan dilakukan proses analisis deskriptif kualitatif untuk menggambarkan, memberikan penjelasan atau keterangan. Dari hasil penelitian tersebut maka akan dilakukan beberapa usaha pengembangan angrowisata anggur dilihat dari potensi yang dimiliki.

Lokasi penelitian ini dilakukan di Desa Banyupoh, Kecamatan Gerokgak, Kabupaten Buleleng $\pm 60 \mathrm{~km}$ dari pusat kota Singaraja. Adapun objek yang diteliti adalah pengembangan agrowisata berbasis anggur yang ada di Desa Banyupoh karena keterbatasan kesadaran masyarakat dalam memanfaatkan lahan perkebunan mereka.

Subjek penelitian yang dimaksud yaitu pengelola dan pihak yang memiliki wewenang memberikan data yang bersangkutan dengan penelitian ini.Pengelola (petani anggur) dan perangkat desa dipilih sebagai subjek dalam penelitian ini karena sumber tersebut dapat memberikan penjelasan yang sesuai dengan penelitian yang dilakukan.

Sedangkan objek penelitian ini dimaksudkan pada penelitian mengenai usaha yang dilakukan pihak pengelola dalam pengembangan lahan pertanian sebagai daya tarik agrowisata.

Data Primer yaitu data yang bersumber dari observasi dan wawancara langsung kepada masyarakat dan perangkat desa dalam mengembangkan Desa Banyupoh sebagai daerah tujuan agrowisata.

Data skunder yaitu data yang dapat diperoleh melalui hasil buku-buku pedoman perhotelan yang terkait dengan penelitian tentang usaha pengembangan agrowisat.

Teknik pengumpulan data yang dilakukan secara langsung pada objek penelitian. Dalam hal ini maka akan dilakukan beberapa penelitian mengenai pemanfaatan lahan pertanian sebagai daya tarik agrowisata. Observasi yang dilakukan menggunakan checklist yang digunakan untuk pengumpulan data penting yang didapat dari narasumber atau yang berwenang memberikan informasi tentang penelitian ini.

Teknik pengumpulan data dengan melakukan tanya jawab 
langsung dengan responden seperti Pengelola serta orang-orang yang berwenang untuk memberikan informasi tentang masalah yang terkait. Dimana metode ini digunakan untuk mendapatkan jawaban langsung dari aparat desa maupun masyarakat atau petani sebagai objek utama dalam penetilian ini.Dalam melakukan wawancara diperlukan adanya pedoman wawancara dan buku catatan, pedoman wawancara ini berfungsi untuk meluruskan percakapan ketika melakukan wawancara agar hal yang dibahas tidak jauh melebar dari materi, sedangkan buku catatan berfungsi untuk mencatat semua data yang di dapat oleh para narasumber, dan memudahkan pengolahan data.

Teknik pengumpulan data dengan melakukan tanya jawab langsung dengan responden seperti Pengelola serta orang-orang yang berwenang untuk memberikan informasi tentang masalah yang terkait. Dimana metode ini digunakan untuk mendapatkan jawaban langsung dari aparat desa maupun masyarakat atau petani sebagai objek utama dalam penetilian ini.

Dalam melakukan wawancara diperlukan adanya pedoman wawancara dan buku catatan, pedoman wawancara ini berfungsi untuk meluruskan percakapan ketika melakukan wawancara agar hal yang dibahas tidak jauh melebar dari materi, sedangkan buku catatan berfungsi untuk mencatat semua data yang di dapat oleh para narasumber, dan memudahkan pengolahan data.Teknik pengumpulan data dengan cara mengumpulkan dokumen dan faktafakta yang ditemukan sebagai acuan dalam penyelesaian penelitian ini. Dalam hal ini digunakan kamera untuk mendapatkan gambar yang berkaitan dengan penelitian ini.

Setelah melakukan teknik pengumpulan data maka selanjutnya adalah menganalisis data. Dalam penelitian ini menggunakan Konsep 4A (Attraction,Accessibillity, Amenity, and Ancilary) dan Analisis SWOT (Strength, Weaknesses, Opportunities, and
Threats) untuk mengetahui kekuatan, kelemahan, peluang dan ancamandan selanjutnya akan digunakanteknis analisis deskriptif kualitatif yaitu dengan mengurai data sistematis memaparkan bagaimana peran masyarakat dalam upaya mengembangankan desa sebagai daerah tujuan agrowisata.

\section{HASIL DAN PEMBAHASAN}

Faktor Pendukung Pengembangan Agrowisata di Desa Banyupoh Dilihat Berdasarkan Konsep 4A (Attraction, Accessibillit, Amenities, and Ancillary)

\section{Attraction}

Atraksi yang dimiliki Desa Banyupoh adalah atraksi agrowisata perkebunan anggur yang berpotensi mampu menarik wisatawan.Sejauh ini ada beberapa investor tertarik untuk mengembangkan Desa Banyupoh sebagai daya tarik agrowisata.Ada beberapa lokasi atau perkebunan anggur yang menjadi pertimbangan para investor untuk dijadikan sebagai kawasan agrowisata. Perkebunan tersebut berlokasi $4 \mathrm{~km}$ dari pusat Desa Banyupoh dengan luas perkebunan sekitar 5 hektar yang dibagi menjadi 3 lokasi karena perkebunan tersebut dikelola oleh tiga orang petani, yang bernama Gusti Ketut Suarta, Ketut Suarmika dan Gusti Putu Suardika.

Berdasarkan hasil observasi yang dilakukan, lokasi tersebut memang layak untuk dikembangkan sebagai wisata agro. Selain lokasi yang sangat strategis, dekat dengan alam dan jauh dari keramaian, penataan dilokasi perkebunan tersebut terbilang telah tertata dengan rapi, hal ini dapat dilihat dari jalan masuk atau gang menuju perkebunan anggur dibangun dengan menggunakan jalan beton sejak tahun 2008 silam dengan lebar jalan/gang 150 $\mathrm{m}$. Jalan/gang tersebut dibangun dari bantuan dana dari PNPM dan Swadaya Masyarakat. Dengan menggunakan jalan beton maka dapat menambah keasrian lokasi perkebunan anggur.

Selain memiliki potensi pengembangan agrowisata, Desa Banyupoh juga memiliki daya tarik 
wisata budaya (Cullur) dan atraksi alamyang kurang dimanfaatkan oleh maryarakat dan desa. Hal tersebut dapat dilihat dari adanya beberapa pura ( tempat persembahyangan Umat Hindu) seperti Pura Agung Pulaki dan pura pabean yang terkenal akan monyet dan Sunsetnya yang indah. Pura Melanting yang terkenal dengan sebutan Pura Pasar (peken), terdapat candi atau bangunan Pura yang megah dan besar, selain itu tradisi membuat uang logam (Pis Bolong) Masih dipertahankan sampai saat ini. Pemaanfaatan atraksi alam yang Ada di Desa Banyupoh juga saat ini terbilang sudah dimanfaatkan dengan baik, dapat dilihat dari penggunaan untuk latihan kemiliteran DODIKLATPUR (Depo Pendidikan Latihan Tempur) Desa Banyupoh.

\section{Accessibility}

Aksesibilitas menuju objek wisata terbilang mudah dan layak, dapat dilihat dari infrastruktur jalan yang sudah beraspal walaupun terdapat beberapa trek jalan yang berkelak-kelok, menanjak dan dan sedikit bergelombang.Sebagian dari beberapa jenis kendaraan mampu untuk melewati jalan tersebut.Kedua adalah lokasi kebun petik buah anggur mudah diakses dengan transportasi umum hanya saja yang menjadi kendala adalah tempat parkir tidak tersedia dan biasanya para wisatawan yang datang memarkir kendaraan mereka di pinggir jalan dan itu tidak mengganggu pengendara lain karena lokasi jarang dilewati kendaraan besar, hal tersebut masih bisa diatasi. Namun demikian, alat tranportasi besar seperti Bus Pariwisata belum dapat melintas dijalan tersebut mengingat lebar jalan hanya \pm 2 meter.Dilihat dari kondisi tersebut maka perlu adanya pengembangan aksesibilitas dari masyarakat dan pemerintah terutama dalam memperbaiki infrastruktur jalan agar kepepan menjadi lebih baik.

\section{Amenities}

Dalam pengembangan objek wisata Desa Banyupoh saat ini sudah ada beberapa investor dari luar negeri yang ingin membeli atau hanya mengontrak tanah dibeberapa lokasi untuk rencana pembuatan villa, hanya saja masyarakat masih belum menyetujui karena masih takut jika tanah mereka dialih fungsikan mengingat pemikiran masyarakat masih minim.Berselelahan dengan Desa Banyupoh yaitu Desa Pemuteran, saat ini perkembangan Pariwisata semakin pesat, banyak akomodasi yang tersedia di Desa Pemuteran, jarak yang ditempuh juga tidak terlalu jauh hanya kurang dari 10 menit menuju Desa Banyupoh dan sebaliknya.

Untuk kedepan perlu adanya fasilitas yang memadai utuk mempermudah kegiatan atau aktivitas para wisatawan, adapun fasilitas yang dapat mendukung suatu daerah tujuan wisata seperti pembangunan fasilitas akomodasi yang memadai, warung atau kios cinderamata, parkir dan toilet. Dengan adanya fasilitas-fasilitas tersebut maka para wisatawan akan merasa puas jika segala kebutuhannya dapat disediakan ditempat yang sama.

\section{Ancillary}

Untuk saat ini tidak ada pengurus/kelembagaan terkait didalamnya, perlu di bentuk beberapa pengurus/kelembagaan sebagai pemandu wisata agar nantinya para wisatawan dapat mengetahui lebih lengkap mengenai keadaan agrowisata . oleh karena itu, pihak pengelola hendaknya mempersiapkan rencanarencana dimasa mendatang untuk perkembangan agrowisata di Desa Banyupoh. Selain membentuk struktur organisasi pengelolaan untuk memperjelas kelembagaan perlu juga diadakan kelompok sadar wisata atau Pokdarwis yang dapat mempererat kelembagaan ditingkat masyarakat dengan tujuan untuk meningkatkan kesadaran masyarakat dalam memanfaatkan potensi yang ada.

\section{Pengembangan Agrowisata Dilihat Berdasarkan Analisi SWOT (Strengths, Weakness, Opportunit, Threath)}




\section{Kekuatan (strengths) Berdasarkan Faktor Internal}

Berdasarkan hasil dari observasi, yang mejadikan kekuatan agrowisata Desa Banyupoh adalah perkebunan anggur.memetik buah anggur langsung dari pohonnya bisa menjadikan daya tarik bagi para wisatawan untuk berkunjung. Selain itu wisatwan juda dapat menikmati langsung buah anggur dari pohonnya. Selain itu budaya masyarakat (culturally) yang ada di Desa Banyupoh juga sangat mendukung sebagai potensi tambahan, dengan adanya beberapa Pura (tempat persembahyangan umat Hindu) Khayangan Jagat Pura Agung Pulaki, Pura Melanting, Pura Kerta Kawat, Pura Pabean, dan Pura Luhur Pucak Manik. Wisatawan yang berkunjung ke Desa Banyupoh bisa mendapat dua manfaat pengetahuan sekaligus yaitu, Agro Tourism dan Cultural Tourism.Dengan adanya dua faktor pendukung tersebut maka Desa Banyupoh layak untuk dijadikan sebagai salah satu daerah tujuan Wisata Agro. Daya tarik wisata lain yang bisa dinikmati di Desa Banyupoh adalah suasana pedesaan yang masih alami. Bercocok tanam atau bertani menjadikan kegiatan sehari-hari sebagai sumber mata pencaharian desa setempat.Keadaan alam dengan cuaca dan iklim, membuat kegiatan pertanian serta perkebunan menjadi sangat cocok dilakukan di daerah ini. Dengan konsep "Memetik Buah Anggur Langsung Dari Pohon" Desa Bayupoh memiliki potensi yang dapat menjadi kekuatan dari objek wisata agro. Adapun faktor lain yang menjadi kekuatan pengembangan agrowisata di Desa Bayupoh adalah:

- Memiliki wilayah yang cocok di tanami taman anggur

- Memiliki tempat yang strategis karena berada dekat dengan alam, selain berpotensi sebagai wisata agro Desa Banyupoh juga berpotensi sebagai pariwisata budaya.

- Memiliki konsep agribisnis yang menarik, yaitu " petik sendiri buah anggur dari lahan yang ada”.
- Memiliki keindahan pemandangan alam di sekitar kebun karena berada di daerah pegunungan.

\section{Kelemahan (weakness) Berdasarkan Faktor Internal}

Sebagai salah satu yang menjadi kelemahan untuk menjadikan Desa Banyupoh sebagai daerah tujuan wisata adalah ada beberapa sarana dan prasarana yang kondisinya kurang baik atau rusak seperti infrastruktur jalan, sarana akomodasi (penginapan dan rumah makan/restoran) yang tidak bertempat di Desa Banyupoh, atraksi wisata yang belum dimanfaatkan secara maksimal. Adapun faktor lain yang menjadi kelemahan pengembangan agrowisata di Desa Bayupoh adalah:

- Belum memiliki lahan parkir yang memadai.

- Pemilik kebun belum menyetujui tentang pemanfaatan lahan perkebunan anggur mereka.

- Belum banyak bir-biro perjalanan wisata yang memilih kebun petik buah anggur sebagai salah satu tempat tujuan wisata yang mereka buat dalam paket tour.

- Belum tersedianya beberapa fasilitas penunjang lainnya

\section{Peluang (Opportunity) Berdasarkan Faktor Eksternal}

Desa Bayupoh dapat menjadi daerah tujuan wisata agro jika adanya minat serta dukungan masyarakat dan pemerintah dalam rencana pengembangan potensi agrowisata yang ada di Desa Banyupoh, penghasilan masyarakat di sekitar daerah kawasan agrowisata akan bertambah sehingga meningkatkan taraf hidup masyarakat, membuka lapangan pekerjaan, sehingga mengurangi pengangguran, dan dapat meningkatkan pendapatan asli daerah (PAD). Adapun faktor lain yang menjadi peluang pengembangan agrowisata di Desa Bayupoh seperti adanya internet yang memberi kesempatan untuk meningkatkan promosi.

\section{Ancaman (Threath) Berdasarkan Faktor Eksternal}


Seperti yang diketahui pada umumnya di Kabupaten Buleleng memiliki banyak objek wisata yang indah dan menarik untuk dikunjungi para wisatawan.Oleh karena itu, Agrowisata Bedugul menjadi ancaman besar bagi Perkembangan Agrowisata Desa Banyupoh.Selain itu, banyak bermunculan desa wisata yang berbasis Comunity Based Tourism, sehingga persaigan relatif ketat khususnya dengan wisata angro yang dipegang oleh Sababay Winery Bali.Adanya tempat wisata lain yang jaraknya tidak terlalu jauh walaupun jenis wisata yang ditawarkan berbeda namun sangat menarik para wisatawan untuk berkunjung seperti penangkaran terumbu karang yang menawarkan aktivisa seperti daiving \& snorkling yang bertempat di Desa Pemuteran tepat bersebelahan dengan Desa Bayupoh.

\section{Pengembangan Agrowisata Anggur}

Keuntungan dari pengembangan agritourismbagi petani local dapat dirinci sebagai berikut menurut Lobo dkk, 1999.

1)Agriturism dapat memunculkan peluang bagi petani lokal untuk meningkatkan pendapatan dan meningkatkan taraf hidup serta kelangsungan operasi mereka.

2)Menjadi sarana yang baik untuk mendidik orang banyak/masyarakat tentang pentingnya pertanian dan kontribusinya untuk perekoniman secara luas dan meningkatkan mutu hidup.

3)Mengurangi arus urbanisasi ke perkotaan karena masyarakat telah mampu mendapatkan pendapatan yang layak dari usahanya di desa (agritourism).

4)Agritourism dapat menjadi media promosi untuk produk lokal, dan membantu perkembangan regional dalam memasarkan usaha dan menciptakan nilai tambah dan "directmarking" merangsang kegiatan ekonomi dan memberikan manfaat kepada masyarakat di daerah dimana agrotourism dikembangkan.

Sedangkan Manfaat Agritourism bagi pengunjung (Rilla, 1999) adalah sebagai berikut:
1) Menjalin hubungan kekeluargaan dengan petani atau masyarakat lokal

2) Meningkatkan kesehatan dan kesegaran tubuh

3) Beristirahat dan menghilangkan kejenuhan

4) Mendapatkan petualangan yang mengagumkan

5) Mendapatkan makanan yang benarbenar alami (organic food)

6) Mendapatkan suasana yang benarbenar berbeda

7) Biaya yang murah karena agrowisata relatif lebih murah dari wisata yang lainnya.

Pengembangan yang dilihat dari kekuatan yang mendukung perkembangan agrowisata dalam upaya pemanfaatan potensi yang ada di Desa Banyupoh, Dengan Konsep "Petik Buah Anggur Langsung Dari Pohon" dapat menarik wisatawan untuk berkunjung. Masyarakat sebagai pengelola hendaknya memberika kenyamanan bagi para wisatawan serta kebersihan lingkungan pada kebun anggur, dengan adanya hal terebut maka wisatawan menjadi tertarik untuk melakukan kunjungan wisata.Selain itu wisatawan juga dapat menikmati wisata culture, seperti mengunjungi pura-pura yang ada di Desa Banyupoh.

Berdasarkan hasil observasi yang telah dilakukan, maka telah ditentukan beberapa lokasi yang sangat mendukung dan berpotensi sebagai daya tarik agrowisata yang menggunakan konsep "Petik Buah Anggur Langsung Dari Pohon". Dilihat dari akses jalan menuju lokasi terbilang mudah dan penataan kebun serta kondisi lingkungan, dengan luas lahan perkebunan anggur \pm 5 hektar dibagi menjadi 3 dalam 1 lokasi yang dapat menarik para investor untuk melakuakan kerja sama dengan para petani.

Berdasarkan hasil wawancara oleh salah seorang pemilik kebun anggur yang bernama Gusti Ketut Suarta mengatakan bahwa, sekitar tahun 2012 Sababay Winery Bali atau perusahaan Wine Bali ingin melakukan kerja sama dengan Pak Gusti, akan tetapi Pak Gusti masih mempertimbangkan matang-matang 
karena banyak perjanjian antara pemilik dan investor yang kurang disetujui oleh kedua belah pihak. Untuk saat ini Beliau hanya mengijinkan perkebunan tersebut sebagai lokasi syuting dari perusahaan wine tersebut tanpa memasang Budget .Tidak hanya dari perusahaan Sababay Winery Bali, salah satu investor dari Jerman yang membuka Villa di Desa Pemuteran. Sekitar tahun 2014 yang lalu beliau juga ingin melakuka kerjasama dengan Pak Gusti, akan tetapi penawaran kerjasama tersebut juga ditolak oleh Pak Gusti dengan alasan kekhawatiran tanah atau perkebunan beliau takut dialih fungsikan dan masih banyak hal lain yang menjadi pertimbangan beliau.

Dengan adanya anggapan tersebut dapat disimpulkan bahwa peran serta masyarakat dalam upaya mengembangkan potensi agrowisata masih terbilang minim, dapat dilihat dari pemikiran masyarakat yang begitu sempit mengenai perkembangan pariwisata saat ini yang dianggap semakin berdampak negatif.

\section{SIMPULAN DAN SARAN}

Dari hasil penelitian ini, ada beberapa kesimpulan yang didapatkan, yaitu sebagai berikut:

1. Pengembangan agrowisata anggur dilihat berdasarkan potensi yang dimiliki serta faktor pendukung dengan menggunakan Konsep 4A. Desa Banyupoh memiliki potensi yang sangat baik untuk dikembangkannya agrowisata anggur. Dalam hal ini jika pihak pengelola dan masyarakat sekitar mampu dan ikut berpartisipasi dalam menjaga kebersihan dan memanfaatkan potensi agrowisata yang ada saat ini tentu akan mampu berkembang sangat pesat dengan para pesaing yang ada disekitarnya.

Atraksi (attraction) yang dimiliki Desa Banyupoh adalah wisatawan bisa melihat langsung bagaimana cara berkebun anggur dengan baik, bisa memetik buah anggur langsung dari kebun, dan melakukan tracking/tracker ke beberapa lokasi karena dekat dengan alam. Selain memiliki potensi wisata agro, Desa Banyupoh juga berpeluang dalam mengembangkan potensi dibidang sosial dan budaya, misalnya wisatawan dapat berkunjung ke tempat persembahnyangan Umat Hindu (Pura) seperti berkujung ke Pura Agung Pulaki yang terkenal dengan banyaknya monyet dan sunset Pantai Pulaki, serta Pura Pasar Melanting yang terkenal dengan kerajinan membuat koin (Pis Bolong). Berkaitan dengan pemanfaatan atraksi yang dimiliki Desa Banyupoh, sejak tahun 1940 telah didirikannya asrama kemiliteran yang bernama Dodiklatpur dengan memanfaatkan kawasan Desa Banyupoh sebagai lokasi pelatihan. Atraksi alam sangat mendukung dalam melakukan latihan kemiliteran seperti penjelajahan dan lain sebagainya. Maka dari itu Desa Banyupoh memiliki atraksi alam yang perlu dimanfaatkan.

Accessibility (aksesibilitas) dilihat dari segi aksesbilitas, keadaan insfrastruktur jalan yang sudah beraspal, walaupun ada beberapa trek jalan yang berkelok-kelok, menanjak, dan sedikit bergelombang hal itu masih aman dan tidak membahayakan. Sebagian besar dari jenis kendaraaan mampu untuk melewati jalur tersebut. Namun demikian, alat tranportasi besar seperti Bus Pariwisata belum dapat melintas dijalan tersebut mengingat lebar jalan hanya \pm 2 meter. Kedua adalah lokasi kebun petik buah anggur mudah diakses dengan transportasi umum hanya saja yang menjadi kendala adalah tempat parkir tidak tersedia dan biasanya para wisatawan yang datang memarkir kendaraan merekan di pinggir jalan dan itu tidak mengganggu pengendara lain karena lokasi jarang dilewati kendaraan besar, hal tersebut masih bisa diatasi.

Amenity (amenitas), adanya beberapa investor yang tertarik ingin membeli atau hanya mengontrak tanah dibeberapa lokasi untuk rencana pembuatan villa, hanya saja 
masyarakat masih belum menyetujui karena masih takut jika tanah mereka dialih fungsikan mengingat pemikiran masyarakat masih minim. Berselelahan dengan Desa Banyupoh yaitu Desa Pemuteran, saat ini perkembangan Pariwisata semakin pesat, banyak akomodasi yang tersedia di Desa Pemuteran, jarak yang ditempuh juga tidak terlalu jauh hanya kurang dari 10 menit menuju Desa Banyupoh dan sebaliknya. Adapun sarana akomodasi yang tersedia di Desa Pemuteran seperti, Matahari Beach (bintang lima), Adi Assry cottage and Villa (bintang empat), Amertha Bali Villas (bintang tiga), serta masih banyak Hotel Melati yang ada di Desa Pemuteran. Selain itu, terdapat restaurant dan rumah makan seperti Badini Restauran, Taruna Restaurant, Rumah Susu dan masih banyak jenis restauran/rumah makan yang tersedia.

Ancilliary berkaitan dengan ketersediaan sebuah organisasi atau orang-orang yang mengurus destinasi dapat disimpulkan bahwa tidak ada pengurus/kelembagaan terkait yang berperan didalamnya. Perlu adanya kelembagaan dan pemandu wisata yang ingin mengetahui lebih lengkap tentang keadaan agrowisata yang ada di Desa Banyupoh pada khususnya dan masyarakat Desa Banyupoh pada umumnya.

2. Kekuatan (strenght) yang dimiliki Desa Banyupoh sebagai agrowisata adalah kegiatan rekreasi dengan konsep "Petik Buah Anggur Langsung Dari pohon" yang bisa dijadikan kekuatan. Dengan memiliki pemandangan alam yang asri dan memiliki wisata budaya (Cultur), menjadikan kekuatan dikembangkannya agrowisata ini lebih diminati jika masyarakat sadar akan potensi yang dimiliki.

Kelemahan (weakness) yang dimiliki oleh Desa Banyupoh sebagai pengembangan agrowisata yaitu memiliki beberapa permasalahan yang menjadi kelemahan dari objek wisata salah satunya penataan kebersihan desa tersebut masih kurang. Dapat dilihat dari fasilitafasilitas yang belum tersedia, beberapa sarana dan prasarana yang kondisinya kurang baik atau rusak seperti infrastruktur jalan, sarana akomodasi (penginapan dan rumah makan/restaurant) yang tidak bertempat di Desa Banyupoh, atraksi wisata yang belum dimanfaatkan secara maksimal.

Peluang (Opportunity) Beberapa faktor pendukung dari luar dapat menjadikan peluang bagi Desa Banyupoh untuk dikembangkan sebagai kawasan wisata yang diminati para wisatawan. Desa Banyupoh yang memiliki kondisi alam yang masih alami serta perilaku penduduk yang masih serat akan budaya. Faktor pendukung dari luar lainnya adalah dengan semakin berkembangnya pariwisata dikawasan Bali Barat, perkembangan pariwisata di Desa Pemuteran yang semakin pesat, tepat bersebelahan dengan Desa Banyupoh. Hal tersebut akan menjadikan peluang untuk mempromosikan potensi Desa Banyupoh. Melihat potensi pertanian yang ada di Desa Banyupoh terutama perkebunan anggur sangat mendukung dikembangkannya wisata agro. Tren atau keinginan wisatawan untuk beralih ke suasana alam dan budaya menjadikan peluang yang baik dengan dikembangakannya wisata agro di Desa Banyupoh. Selain itu peluang angrowisata anggur relatif tinggi dikarenakan di Bali baru terdapat satu jenis wisata agro yang sama tetapi jenis anggur berbeda yaitu anggur hijau yang dikelola oleh perusahaan Sababay Winery Bali. Kebun tersebut berlokasi di Desa Sangalangit Kecamatan Gerokgak dengan luas lahan \pm 50 are.

Ancaman (threath) Perkembangan pariwisata Agrowisata Bedugul menjadi ancaman besar bagi Perkembangan Agrowisata Desa Banyupoh. Selain itu, banyak bermunculan desa wisata yang 
berbasis Comunity Based Tourism, sehingga persaigan relatif ketat khususnya dengan wisata angro yang dipegang oleh Sababay Winery Bali.

Saran yang dapat disampaikan sehubungan dengan hasil penelitian mengenai hasil penelitian dengan menggunakan konsep 4A dan menggunakan hasil Analisis SWOT di Desa Banyupoh sebagai pengembangan agrowisata, yaitu sebagai berikut:

1. Untuk Petani atau pengelola

Saran yang bisa diberikan kepada petani atau pengelola khususnya petani anggur yaitu diharapkan petani menyadari dan bisa memanfaatkan potensi yang ada dengan mengembangakan menjadi kawasan wisata yang dapat menarik para wisatawan.

2. Untuk Masyarakat

Saran yang bisa diberikan kepada masyarakat Desa Banyupoh adalah masyarakat bisa lebih ikut berperan aktif dalam mengembangkan objek wisata yang terdapat di Desa Banyupoh. Salah satunya dengan menambah produk yang ada dengan melihat potensi yang dimiliki.Masyarakat bisa membuka usaha seperti menjual kerajinan tangan atau menjual aksesories guna menarik para wisatawan untuk berkunjung ke Desa Banyupoh.

3. Untuk Peneliti Selanjutnya

Untuk peneliti selanjutnya disarankan untuk melakukan penelitian yang terkait dengan pengembangan agrowisata yang nantinya dapat menambah perkembangan wisata agro di daerah yang berbeda

\section{DAFTAR PUSTAKA}

\section{About Agritourism at http://www.farmstop.com/aboutagrit ourism.asp}
Bambang Pamulardi. 2006. Pengembangan Agrowisata Berwawasan Lingkungan di Desa Wisata Tingkir, Kecamatan Salatiga".

http://penelitian.pengembangan.agr owisata.com

Deptan, 2005."Agrowisata Meningkatkan Pendapatan Petani" pada http://database.deptan.go.id

http://geograph88.blogspot.co.id/2014/1 $1 /$ potensi-fisik-dan-non-fisikdesa.html

http://www.jejakwisata.com/tourismstudies/tourism-in-general/213-4ayang-wajib-dimilki-oleh-sebuahdestinasi-wisata.html jejak wisata.com

I Ketut Seten dkk. 2010. "Buku Besar dan Sejarah.

LIPI. 2005. "Kebun Raya Bogor : Cikal Bakal Perpustakaan Indonesia" pada

http://www.lipi.go.id/www/www.cgi?c etak\&1111211845

Lobo, R.E., Goldman G.E. and others. 1999. Agricultural Tourism: Agritourism Benefits Agriculture in San Diego County, California Agriculture, University of California.

Muzha VK, Ribawanto H, Hadi M. 2013. Pengembangan agrowisata dengan pendekatan Community Based Tourism (Studi pada Dinas Pariwisata Kota Batu dan Kusuma Agrowisata Batu). Jurnal Administrasi Publik. Jurnal Elektronik Mahasiswa Jurusan Administrasi Publik.1(3) http://administrasipublik.studentjour nal.ub.ac.id/index.php/jap/article/vie w/81/75 [27 Mei 2013].

Pitana, I Gde. 2002. "Pengembangan Ekowisata di Bali”. Makalah Disampaikan pada Seminar Ekowisata di Auditorium Universitas Udayana pada tanggal 29 Juni 2002.

Salyo Sutrisno. 2009. "Pengembangan agrowisata berbasis salak di Kabupaten Ponorogo" pada 
http://penelitian.pengembangan.agr owisata.com

Spillane, James.1994. Ekonomi Pariwisata, Sejarah dan prospeknya.Yogyakarta: Kanisius.

Syamsu dkk. 2001. "Penerapan Etika Perencanaan pada kawasan wisata, studi kasus di kawasan Agrowisata Salak Pondoh, Kabupaten Sleman, Daerah Istimewa Yogyakarta". Jakarta: LP3M STP Tri Sakti, Jurnal IImiah, Vol 5. No. 3 Maret 2001. 